\title{
Childhood memories in three novels by Philip Roth: Portnoy's Complaint, The Plot Against America, and American Pastoral as pivotal components of the protagonists' identities
}

\begin{abstract}
The objective of the paper is to discuss Philip Roth's approach to the Jewish community in Newark, where he spent his childhood and where he chose to set several of his novels. Roth's narrations referring to his hometown are written in the first person singular and often take the form of childhood memories. The persistent return to the settings of the Jewish quarter of Newark in the past seems an attempt at understanding the reality of a relatively closed community, yet far from isolation, which provided him with all the elements determining his complex sense of identity. Despite the various grades of fictitiousness of the characters and settings, the narrating protagonist of a number of Roth's novels is usually a Jewish schoolboy born and brought up in Newark. The paper includes short analyses of "Jewish memories" in three novels by Philip Roth: The Plot Against America, where the narrator is called Philip Roth but the circumstances are elements of pure political/historical fiction, American Pastoral, where the speaker is Nathan Zuckerman, Roth's frequent alter ego, and Portnoy's Complaint, narrated by the fictitious Alexander Portnoy. Being both American and Jewish has considerable implications, which include, for example, the characters' sexuality. The image of the childhood and adolescence of Roth's protagonists seems not only an obsessive theme to be found in so many of his texts, but also the core of the intellectual construct which may be recognized as his sense of identity.
\end{abstract}

Keywords: childhood, memory, Jewishness, Jewish identity, Philip Roth.

\section{Introduction}

This article is an attempt to follow a mechanism of constructing the cultural identity of the protagonists of three novels by Philip Roth. The criteria of their selection and the order of their presenting is the importance of Jewishness in the main characters' narrations. Therefore, the first book discussed in this paper is Portnoy's Complaint, the protagonist of which carries out a permanent argument with the Jewish tradition imposed, as he believes, upon him by his family. Being a Jew in The Plot Against America plays an extremely important role, although the main character and narrator is much younger than Alex Portnoy, and he may be treated as more prone to the circum- 
stances that form his personality and attitude to his own identity. The narrator of American Pastoral, Nathan Zuckerman, tells the story of a person whose Jewishness seems to be of little importance save certain moments where his father's strong sense of Jewish identity and its effect on the protagonist are mentioned. However, the narrator dedicates quite a number of introductory pages to the description of the Jewish neighbourhood where both he and the character whose story he tells grew up. I will try to demonstrate that in the secular world, where all apparent components of Jewish identity cease to be of much importance, the narrators are not able to avoid constructing their identities, which are still Jewish. The construction of Jewish identity is based on childhood and adolescent memory. Through the analysis of the narration of particular parts in the novels, especially those dedicated to certain recurring elements which refer to Jewish lifestyle and Jewishness in general, I shall try to demonstrate the implied author's ${ }^{9}$ attitude towards them, which, in the case of Philip Roth, will inevitably lead to the real author, whose background includes, not coincidentally, the same elements which can be found in almost all his novels.

\section{Memory and identity}

Attributing such an important role to memory requires certain explanation. Recent memory studies demonstrate clearly that a human mind is not the best instrument to store data consisting of explicit facts accompanied by specific circumstances. It is undeniable that memory is deceptive and distorts the image of past reality. As Martin Pollack observes, no bad intentions, deliberate confabulation or concealment are necessary to let one's memory erase one event and "invent" another, or rearrange the chronological order of facts and events (Pollack, 6).

It is important to take into consideration the fact that, as Katherine Nelson asserts,

The general function of memory is to predict and prepare for future encounters, actions, and experiences

.... That is, memory as such has no value in and of itself, but takes on value only as it contributes to the individual's ability to behave adaptively. (Quoted in Sabbagh, 55)

In the light of this assertion, constructing one's identity through memories does not require their accuracy. It suffices that they provide individuals with protective/adaptive instruments to survive in any environment, including society and a local community, a part of which they are or may become.

Individuals' memories depend on their emotional approach to the places, objects or people they recollect. As the psychiatrist, Donald Spence, observes:

$[$ P]eople often will feel dissatisfied when ... they go back to their elementary school or their college

9 A concept proposed by Wayne C. Booth in his book The Rhetoric of Fiction, where "the implied author" is "the second self-created in the work," whose beliefs are consistent but not necessarily identical with those of the real author (Booth, 137). 
fraternity - because looking at the real object does not substitute for remembering it, because the remembering, often inadvertent, is embedded in a specific situation with its special context and its own dynamics. A trip to the fraternity house is simply a trip, and it produces a sense of disappointment because it is deprived of the critical surround. (Quoted in Sabbagh, 28)

Thus, inasmuch as remembrance is the process of reconstruction, it also contains elements of construction, which results from current emotional and social needs. A confrontation with physical objects recollected for the purpose of constructing one's identity may either ruin the construction or reinforce it. Nevertheless, no memory precision seems necessary to build the sense of identity.

According to the social psychologist Henry Tajfel, ethnicity is:

[t]hat part of an individual's self-concept which derives from his knowledge of his membership of a social group (or groups) together with the value and emotional significance attached to that membership. (Tajfel, 255)

This short definition may be a point of departure for exploring the issue of Jewish identity in Philip Roth's novels. The question of where this knowledge comes from, or perhaps where, when and how it is produced, seems crucial. The Brazilian sociologist, Bernardo Sorj, maintains that

[s]ocial identity is constructed around an identification with beliefs, symbols, and practices that delimit, or create boundaries, constraining the individual or group tendency to blend with others. Identities allow the construction of 'memories' and narratives of selves and groups. (Sorj, 1)

The fact that memories are not only effects of remembrance but also products of construction seems essential to understand the interconnection between them and identities.

Identity is a construct without which it is difficult to imagine functioning in society. Identities connected with belonging to particular groups or communities often result from several historical and sociological processes. The most popular adjectives to describe collective identities are: national (referring to a particular state or autonomous area), ethnic (usually associated with the language, customs and "tribal" sense of community) and religious.

As regards Jews, it is really difficult to find one satisfactory attribute of their identity. For nearly two thousand years there was no territory which could be referred to as a Jewish state. Over more than two millennia of Diaspora, Hebrew ceased to be the language of everyday communication, and was superseded by Aramaic, Greek and other local languages of the ancient world, and later by Yiddish and Ladino. For all those centuries religion and the customs resulting therefrom were practically the only determinants of belonging to the Jewish people. Political changes in the 19th century brought several new political concepts, including the nation-state and nationalism on the one hand, and on the other hand, modern civil rights, which resulted, for example, in the emancipation of the European Jews. The idea of Jewish identity, for so long associated with religion, commenced its evolution along with abandoning Orthodoxy, assimilation movements, Zionism, 
socialism, and many other factors. The problematic definition of Jewishness tempts certain authors to undermine the very idea of such an identity.

Having gathered considerable material, an Israeli historian, Shlomo Sand, published in 2008 his controversial book titled The Invention of the Jewish People, in which he argues that there is no continuity between the ancient people of Israel, whose biblical history is also dubious. According to Sand, present day residents of the State of Israel are just a result of political ideology rather than a historical fact. In the light of Sand's critical deconstruction of the idea of collective identity, Jewishness loses its clear solid definition and attributes.

Anti-Semitism, especially that of the 20th century, contributed to the beginning of a new type of the sense of Jewishness, based on the threat from the external enemy, who found all the degrees of assimilation irrelevant. The Holocaust became an additional factor that fueled the Zionist efforts to build a country for the Jews in Palestine, the Biblical Promised Land, the state of Israel. The existence of such a political entity provided many Jews with a new concept of identity, which was very similar to that developed in the 19th century in other nation-states. Thus, the loyalty and love of the state of Israel became one of the determinants of the sense of Jewishness. However, in the United States lived quite a number of Jews who did not suffer from the atrocities of the German Nazis or built the state of Israel; who were by no means Orthodox, even though observing the Jewish tradition in its modified, reformed versions. Moreover, the generation of their children may not be religious at all. Having joined the American mainstream lifestyle, many of them still have a feeling of strong affiliation with their ancestry, even though they may be atheists not observing any Jewish rites or customs.

Philip Roth, an American novelist born in 1933 in Newark, New Jersey, has written a number of books set in the Jewish neighbourhood of this city. The writer himself is not a religious Jew, and his texts exposed him to severe criticism on the part of American Jews. However, Jewishness is present in almost all his novels and stories, being a more or less important thread in each of them. A number of Roth's novels are bildungsromans, where the protagonists tell stories about their early years as children of American Jewish parents. The selection of texts to discuss in this paper was determined by the role played by the reference to Jewish childhood. As A. James Rudin observed, "Roth is akin to a literary archeologist who digs deep into his imagination and brings up youthful remembrances of things past to re-create the American Jewish milieu of his youth" (Rudin). In Portnoy's Complaint, published in 1969, Jewishness seems to be a key to understanding the protagonist's identity formation problem. In The Plot Against America (2004), Anti-Semitism determines the importance of being a Jew, whereas in American Pastoral (1997) Jewishness appears with no crucial purpose, since the main character does not seem to attach much importance to his religious or ethnic origins.

The novels differ in terms of the tone of narration. Whereas Portnoy's Complaint is the confession of Alex Portnoy to his psychoanalyst, a long soliloquy full of irony and humour, The Plot Against America is a serious alternative history, though not devoid of self-sarcastic elements of the protagonist's narration, where the narrator recalls the presidency of the famous aviator Charles Lindbergh, known for his sympathy with Nazi Germany. American Pastoral, on the other hand, is 
the poignant portrayal of a tragic relationship between a father and a daughter who has become a terrorist and assassin.

The narrators are also different, even though it is not difficult to perceive similarities between them and the author himself. Whether it is Alex Portnoy or Nathan Zuckerman (American Pastoral), they are all Jewish boys who grew up in Newark, New Jersey in the 1940s and attended Weequahic High School. Philip Roth, the narrator and protagonist of The Plot Against America, is too young for this school but his brother is its student. Naming one of the protagonists after the author himself in The Plot Against America is a kind of literary trick enhancing the impression of authenticity of the account which, of course, cannot be real. Nevertheless, it does not require much effort to discover very strong similarities between Roth characters. It also seems obvious that certainly most of his texts include recurring autobiographical elements, which has been observed by other researchers writing about his works (Kalay, 891).

Novelists have their favorite themes and problems, which sometimes become their obsessions; problems which they attempt, if not to resolve, to reach a deeper insight into. Beside the typical issues of male puberty every boy has to face, being brought up by Jewish parents and growing up in the Jewish community seems to be an obsession, and questions are asked by literary theorists about whether Philip Roth's novels and stories can or should be called "Jewish" in the sense of the classification adopted by traditional history of literature, which cannot do without national, if not nationalistic attributes of literary texts. Although "identity-based literary study" may lose its clearly defined grounds (Schreier, 104), it is still fascinating that in spite of Roth's characters' and alter ego's rebellion (and the rebellion of Roth himself) against confining them in any simply understood identities, the Jewishness is simply impossible to evade. As S. Lillian Kremer observed, "[s]elf-reflexivity and exploration of their own nature and status as fiction ... are recurrent themes in Philip Roth’s fiction" (Kremer, 57).

\section{Portnoy's Complaint}

The depiction of the Newark Jewish community in Alex Portnoy's humourous monologue is an example of vivid memory infused with emotions. The protagonist's fascination with masturbation, perfectly normal for a boy of his age, puts him in agony. His problem cannot be called an internal conflict, because he does not seem to struggle with his inclination, but his parents warn him of so many things that he cannot even imagine telling them about masturbation, which entails a chain of hilarious consequences. This experience is very present in Alex's memory:

\footnotetext{
Because I haven't even begun to mention everything I remember with pleasure - I mean with a rapturous, biting sense of loss! All those memories that seem somehow to be bound up with the weather and the time of day, and that flash into mind with such poignancy, that momentarily I am not down in the subway, or at my office, or at dinner with a pretty girl, but back in my childhood, with them. Memories of practically nothing and yet they seem moments of history as crucial to my being as the moment of my conception. (PC, 26)
} 
The rules established by Alex's overbearing mother and whining father inflicted a sense of guilt which he ascribes to Jewish history. He exclaims: "I couldn't even contemplate drinking a glass of milk with my salami sandwich without giving serious offence to God Almighty!" (PC, 33) and sums up: "The guilt, the fears - the terror bred into my bones!" (PC, 33). Furthermore, he calls his parents "the outstanding producers and packagers of guilt" (PC, 35). Even though the reader could interpret the behaviour portrayed by their son as quite common among doting and overprotective parents, Alex Portnoy goes much further. He ascribes their infliction of guilt to the burden of Jewish tradition. He says: "I'm living in the middle of a Jewish joke! I am the son in the Jewish joke only it ain't no joke! Please, who crippled us like this?” (PC, 35) Imploring Dr Spielvogel to explain his problem, Alex Portnoy asks: "Is this the Jewish suffering I used to hear so much about? Is this what has come down to me from the pogroms and persecution? from the mockery and abuse bestowed by the goyim over these two thousand lovely years?" (PC, 35).

Alex's father is no role-model to him. Not educated, frustrated by his low status, Mr. Portnoy feels oppressed and powerless. In contrast, Mrs. Portnoy is a strong, bossy woman who runs the household, and to whom Alex is addicted.

The protagonist is a critical observer of community life. His father's brother, Uncle Hymie, "the only one of my aunts and uncles to have been born on the other side talk with an accent" (PC, 50) is also a successful businessman. He strongly believes that "the only place for a Jew to live is among other Jews" (PC, 51), and consequently forbids his son, Heshie, to stay in a romantic relationship with a shikse, Alice Dembosky. When Heshie is killed in the war the neighbours try to console his parents with the words: “At least he didn't leave you with goyische children" (PC, 58). The way Alex Portnoy describes those events to Dr Spielvogel evokes such a comical effect that the reader has no doubt that the tone of the account is sarcastic.

The conversation with his father, when Alex refuses not only to go to synagogue but also to put on smarter clothes at Rosh Hashana, on the grounds that he does not believe in God, is another signal of his rebellious approach to his Jewish heritage. His father's reaction is also significant when he accuses Alex of ignorance of Jewish history, the Talmud and disrespect to the Jewish people (PC, 61). Alex Portnoy will have an opportunity to visit Israel and confront his sense of Jewishness with that of the Israeli Jews, which results in the conclusion that Israel is not his place, even though America seems not to be, either.

\section{The Plot Against America}

Philip Roth, the protagonist and the first-person narrator of The Plot Against America, is also an intelligent and perceptive boy, who observes the changes in the United States after the election of Charles Lindbergh for president. Along with the depiction of the anti-Semitic mood all over the country and the nationalist course of the president's policy, he introduces the Jewish community of Newark. Whereas the events resulting from the presidency of a friend of Hitler and the Nazis are part of alternative history, what is important to concentrate on is the description of the young protagonist's neighbourhood, which seems so similar to that in other texts by Philip Roth. 
The narrator begins with the portrayal of the Parent-Teacher Association at Chancellor Avenue School. The narrator Philip Roth informs the reader that:

All were Jews. The neighborhood men either were in business for themselves - the owners of the local candy store, grocery store, jewelry store, dress shop, furniture shop, service station, and delicatessen, or the proprietors of tiny industrial job shops over by Newark-Irvington line, or self-employed plumbers, electricians, housepainters, and boilermen - or were foot-soldier salesmen like my father. (PAA, 2)

Among the residents were also Jewish doctors, lawyers and "successful merchants" (PAA, 2).

After the introduction the narrator unfolds the list of the elements which did not determine his concept of Jewishness: "It was work that identified and distinguished our neighbors for me far more than religion. Nobody in the neighborhood had a beard or dressed in the antiquated Old World style or wore a skullcap .... The adults were no longer observant in the outward, recognizable ways, if they were seriously observant at all" (PAA, 4). Moreover, "hardly anyone in the vicinity spoke with an accent" (PAA, 4). Roth makes a clear distinction between his Jewish neighbourhood and other Jewish communities. The Newark Jews spoke and read almost exclusively in English, since a newspaper in English was bought by "ten times more customers" than "the Yiddish daily, the Forvertz" (PAA, 4).

As Roth the narrator observes, "Israel didn't yet exist, six million European Jews hadn't yet ceased to exist, and the local relevance of distant Palestine ... was a mystery to me" (PAA, 4). He admits that he did not understand the periodical visits from a bearded Jew who raised money for "the establishment of the Jewish national homeland in Palestine" (PAA, 4). As far as he is concerned, he did everything any other American child did, including pledging allegiance to the flag and observing national holidays. As he sums up, "[o]ur homeland was America” (PAA, 5).

This boyhood memory demonstrates what being a Jew meant to the generation of the protagonist's parents and how his sense of identity was formed. The adjective that could be placed in front of 'identity' is already elusive, since it can be called neither ethnic nor national, even though for his parents and their peers 'religious' may still make some sense.

On the imaginary plane of Roth's alternative history Jewishness gains an additional definition. The definition triggered by anti-Semites who did not let the Jews forget that they are Jews. This identity imposed by the enemies, regardless of the degree of assimilation of the Jewish community itself, however undesirable, is unavoidable. Anti-Semites in The Plot Against America do not want people with this defined identity in their country. Martine Chard-Hutchinson perceives Alvin's (the protagonist's cousin mutilated in the war) stump as

the icon of Jewishness in America or what it means to be a Jew when your identity is only defined in the negative - best summed up in: "What they were was what they couldn't get rid of — what they couldn't even begin to want to get rid of" [Plot 220]. Like the stump (Chard-Hutchinson, 149). 


\section{American Pastoral}

It takes a while before the reader realizes that American Pastoral is the harrowing story of a father whose daughter became an assassin, planting explosives in public places and killing innocent people. Being a paragon for his fellow students at Weequahic High School for his sporting achievements and general moral decency, Seymour 'Swede' Levov is unable to cope with his 16-year-old child. 'Swede' owes his nickname to his blond hair and 'Nordic' appearance. If not for his parents' visits, for whom being Jewish matters, the reader could find the Jewishness irrelevant. Nevertheless, Nathan Zuckerman, Philip Roth's narrator, dedicates a number of pages to introducing the reader to the Newark Jewish community. His school reunion provides him with a pretext to reconstruct the Jewish district and its inhabitants back in the 1940s:

Keer Avenue was where the rich Jews lived - or rich they seemed to most of the families who rented apartments in the two-, three- and four-family dwellings with the brick stoops integral to our afterschool sporting life .... Here, on this grid of locust-tree-lined streets into which the Lyons farm had been partitioned during the boom years of the early twenties, the first postimmigrant generation of Newark's Jews had regrouped into a community that took its inspiration more from the mainstream of American life than from the Polish shtetl their Yiddish-speaking parents had re-created around Prince Street in the impoverished Third Ward. The Keer Avenue Jews, with their finished basements, their screened-in porches, their flagstone front steps, seemed to be at the forefront, laying claim like audacious pioneers to the normalizing American amenities. (AP, 10)

It is important to underscore the inspiration taken from the mainstream of American life. These American Jews are still strongly emotionally attached to their Jewishness, even though it is difficult to assess their children's sense of identity. Nathan Zuckerman, the non-religious narrator, refuses to bother to describe his cohorts' attitude to their ethnic or religious affiliation. However, the memories reaching back to their school years demonstrate how much their childhood and adolescence is present in their life, including their Jewish parents. Zuckerman, in his never delivered speech, wrote:

Am I wrong to think that we delighted in living there? No delusions are more familiar than those inspired in the elderly by nostalgia, but am I completely mistaken to think that living as well-born children in Renaissance Florence could not have held a candle to growing up within aromatic range of Tabachnik's pickle barrels? (AP, 42)

Zuckerman remembers the post war energy and ambition characterizing his neighbourhood back in the 1940s, "despite a generalized mistrust of the Gentile world" (AP, 41). The country was recovering from the Depression and "the place was bright with industriousness" (AP, 41) The place and its residents had to determine their children's mentality. However, the Jewish tradition and lifestyle had not necessarily become its component. 'Swede's' Levov's cynical brother, Jerry, 
describing the post-school life of Seymour, calls his wife "post-Catholic" and his brother "postJewish," who were going to raise "little post-toasties" (AP, 73).

The main character, Seymour 'Swede' Levov, hardly mentions his Jewish origins. He is absolutely against forcing his newly-wed Irish Catholic wife Dawn to convert to Judaism, which is his mother's idea. As he admits, Judaism means nothing to him. In the flashback of his early days in their house in Old Rimrock his new acquaintance invites him to join the local Jewish congregation with their own temple. This triggers Seymour's memories, reaching back to his childhood, with his father as a person whose religiousness he perceived as false and superficial. As he confesses to Dawn: "I didn't come out here for that stuff. I never got that stuff anyway" (AP, 314), which a clear signal that religion cannot have been of great importance in his formative years. "Even seeing my father there never made sense. It wasn't him, it wasn't like him - he was bending to something that he didn't have to, something he didn't even understand. He was bending to this because of my grandfather" (AP, 314). Seymour concludes his account of his father's Judaism with the thought that the old businessman Lou Levov's expertise in gloves surpassed his knowledge of God.

The reader may infer that Lou Levov was his older son's role model because of his integrity and the high moral standards which can be found in Seymour himself. Probably his father's hesitant and shallow faith, if not just vacant participation in traditional rituals, inadvertently affected the boy's attitude towards religion.

\section{Philip Roth and Jewishness}

Detecting the implied author in Roth's fiction is not a challenging task. He is an expert on the Jewish district of Newark, where young people attend Weequahic High School. The implied author speaks through his narrators, who are Jewish males of different ages and who love recalling their Jewish parents and neighbours.

As Alan Cooper observes, referring to a number of Roth's texts, in all his

first person narratives, the easiest kind to confuse with autobiography, particular aspects of the Jewish difference early become obsessive challenges to the protagonists. For Portnoy Jewish restraint is symbolized in the kashruth laws, which the culture extends to anything that comes in contact with the mouth, to unkosher sex, to social interaction with Gentiles. (Cooper, 63)

The characters of Roth's novels suffer from the problem of identity, which can be explained with their teenage rebellion affecting the rest of their lives. Robert Greenberg, like many other commentators, sees the strong influence of the author's own experience and feelings.

Roth's frustration with his subcultural position as a Jew in American society is, in many ways, the irritant that produces his fiction. His irritation, however, is not simply the result of overt resistance by mainstream society. His frustration is also clearly determined by his position in Jewish-American culture - by his embroilment in and rebellion against the world of his parents. (Greenberg, 481) 
Even though Roth's protagonists are completely different characters, the recurrence of certain topoi entitles the reader to look for a quite clear message permeating all his texts. Much as we would like to separate the author from the figures he created, it is inevitable to conclude that he obsessively returns to the issue of Jewishness as if he tried to define a problem he deals with every time he writes a book: a problem with no possible ultimate solution.

Roth's critical approach to the generation of his parents, who personify the Jewish tradition in the protagonists' eyes, even though the former are far from Jewish Orthodoxy, provoked strong criticism from certain Jewish circles in America. He was even accused of promoting "'self-loathing' Jews who provided anti-Semitism with confirmation and validation for their hatred of Jews and Judaism" (Rudin). In 2014, Roth was honoured by the Jewish Theological Seminary in New York City, the chancellor of which, Arnold Eisen, had no doubts about Roth's real intentions behind his texts:

His questions about Jewish life and identity and their dilemmas have always been the right questions, even if I haven't always agreed with his answers. The outrage that greeted his early work belongs to another era, and so does the sense of being a pariah. (Rudin)

In response, Philp Roth joked "I have not been embraced by a gathering like this since March of 1946, when my family and friends were assembled to celebrate my bar mitzvah" (Rudin).

However elusive Jewish identity is, and however critical of the Jewish tradition Roth and his protagonists are, the author of Portnoy's Complaint has never ceased to feel strong bonds with his cultural roots.

\section{Conclusion}

Summing up this short review of the elements of identity in three novels by Philip Roth, it is inevitable to conclude that the identity which, for the lack of a better term, could be called ethnic, which resulted from thousands years of Jewish religious tradition, in the generation of descendants of Jewish immigrants in the United States was subject to dramatic yet not revolutionary changes. Far from Jewish Orthodoxy, the protagonists' parents make some effort to remain religious or at least traditional. Their children, like the author Philip Roth himself, can be defined as post-Jewish atheists. Nevertheless, much as they renounce the tradition, they never deny their Jewishness. Being a Jew, whatever this means to them, seems as natural as being a human. Again, the analysis of their sense of identity evades scientific classifications, because without the religion, without the language, without the nation-state (which now exists, but anyway their home is America), without the tradition superseded by American customs, it is theoretically impossible to find anything Jewish in them. However, the Jewishness seems to remain a very strong element of their personalities and accompanies them throughout life. It is memory, in particular the memory of their childhood, which is unique, sometimes stormy yet happy, and foremost Jewish. 


\section{References:}

Booth, Wayne C. 1983. The Rhetoric of Fiction. Second Edition. Chicago: The University of Chicago Press.

Chard-Hutchinson, Martine. 2009. “'Perpetual Fear': Repetition and Fantasy in The Plot against America by Philip Roth.” Human Architecture Journal of the Sociology of Self-Knowledge, VII.2 (Spring), 145-150.

Cooper, Alan. 1996. Philip Roth and the Jews. Albany: State University of New York Press.

Greenberg, Robert. 1997. "Transgression in the Fiction of Philip Roth." Twentieth Century Literature, 43.4, 487-506.

Kalay, Faruk. 2013. "Social Constraints and Identity Problems in Philip Roth's Zuckerman Bound.” The Journal of Academic Social Science Studies JASS 6.8 (Oct.), 889-900. 20 Oct. 2016. www.jasstudies.com/DergiTamDetay.aspx? $I D=1866$

Kremer, S. Lillian. 1998. "Philip Roth's Self-Reflexive Fiction.” Modern Language Studies 28.3/4, 57-72.

Pollack, Martin. 2017. Topografia pamięci. Trans. Karolina Niedenthal, Wołowiec: Czarne.

Roth, Philip. 1969. Portnoy's Complaint. New York: Random House. (PC)

Roth, Philip. 1997. American Pastoral. New York: Vintage Books. (AP)

Roth, Philip. 2004. The Plot Against America. Boston, New York: Houghton Mifflin Company. (PAA)

Rudin, A. James. 2016. “Philip Roth and his Jewish people.” Religion News Service 10 Oct. 2016. 22 Oct. 2016. religionnews.com/2016/10/10/philip-roth-and-his-jewish-people

Sabbagh, Karl. 2009. Remembering Our Childhood: How Memory Betrays Us. New York: Oxford University Press.

Sand, Shlomo. 2008. The Invention of the Jewish People. Trans. Yael Lotan. London. New York: Verso.

Schreier, Benjamin. 2011. “The Failure of Identity: Towards a New Literary History of Philip Roth's Unrecognizable Jew.” Jewish Social Studies 17.2 (Winter), 101-135. 3 May 2016.

Sorj, Bernardo. 2004. "Identity and Jewish Identities." 3 May 2016, www.academia.edu/13724095/ Identity_and_Jewish_Identities

Tajfel, Henri. 1981. Human Groups and Social Identity: Studies in Social Psychology. Cambridge: Cambridge University Press. 